\title{
GRIA3 Gene
}

National Cancer Institute

\section{Source}

National Cancer Institute. GRIA3 Gene. NCI Thesaurus. Code C24461.

This gene is involved in the regulation of neuronal signal transduction and neurotransmitter activity. 